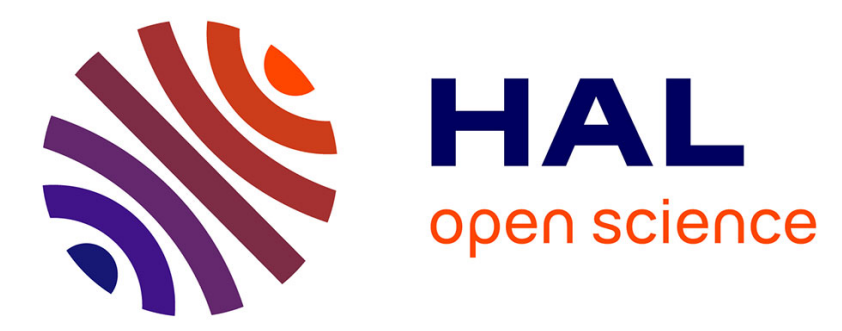

\title{
Some aspects of the reactivity of olivine and serpentine towards different chlorinating gas mixtures
}

Ndue Kanari, Nour-Eddine Menad, I. Gaballah

\section{To cite this version:}

Ndue Kanari, Nour-Eddine Menad, I. Gaballah. Some aspects of the reactivity of olivine and serpentine towards different chlorinating gas mixtures. Thermochimica Acta, 1998, 319, pp. 97-104. 10.1016/S0040-6031(98)00392-X . hal-01508119

\section{HAL Id: hal-01508119 \\ https://hal.univ-lorraine.fr/hal-01508119}

Submitted on 15 May 2017

HAL is a multi-disciplinary open access archive for the deposit and dissemination of scientific research documents, whether they are published or not. The documents may come from teaching and research institutions in France or abroad, or from public or private research centers.
L'archive ouverte pluridisciplinaire HAL, est destinée au dépôt et à la diffusion de documents scientifiques de niveau recherche, publiés ou non, émanant des établissements d'enseignement et de recherche français ou étrangers, des laboratoires publics ou privés. 


\title{
Some Aspects of the Reactivity of Olivine and Serpentine towards Different Chlorinating Gas Mixtures
}

\author{
N. KANARI, N. MENAD* and I. GABALLAH \\ Mineral Processing and Environmental Engineering Team, LEM ${ }^{\mathrm{a}}$ \\ Associated to $\mathrm{CNRS}^{\mathrm{b}} \mathrm{URA}^{2}$ 235, ENSG ${ }^{\mathrm{c}}$, INPL ${ }^{\mathrm{d}}$, BP 40, 54501 Vandœuvre, France \\ * Luleä University of Technology, Process Technology, S 97187 Sweden
}

The reactivity of olivine and serpentine towards $\mathrm{Cl}_{2}+$ air, $\mathrm{Cl}_{2}+\mathrm{N}_{2}$ and $\mathrm{Cl}_{2}+\mathrm{CO}$ was studied in non isothermal conditions up to $1000^{\circ} \mathrm{C}$. The same samples were also chlorinated in a horizontal experimental set during 2 hours between $500{ }^{\circ} \mathrm{C}$ and $1000{ }^{\circ} \mathrm{C}$, under oxidizing and reducing atmospheres. The chlorination products were examined by XRD and SEM.

The iron bearing compounds contained in the olivine and serpentine natural samples can be eliminated through the chlorination or the oxychlorination of these solids at temperatures lower than $900{ }^{\circ} \mathrm{C}$. Carbochlorination of olivine and serpentine is incomplete even at $1000{ }^{\circ} \mathrm{C}$ for a reaction time of $2 \mathrm{~h}$. Pure magnesium chloride can be recovered by cooling the gas phase at about $500{ }^{\circ} \mathrm{C}$.

Key Words : Olivine, Serpentine, Chlorination, TGA, Reactivity

\footnotetext{
a. Laboratoire Environnement et Minéralurgie, rue du Doyen M. Roubault, BP 40, 54501 Vandœuvre Cedex, France.

b. Centre National de la Recherche Scientifique, 3 rue Michel-Ange, 75794 Paris Cedex, France.

c. Ecole National Supérieure de Géologie, rue du Doyen M. Roubault, BP 40, 54501 Vandœuvre Cedex, France.

d. Institut National Polytechnique de Lorraine, 2 rue de la Forêt de Haye, 54501 Vandœuvre Cedex, France.
} 


\section{INTRODUCTION AND LITERATURE REVIEW}

Chlorination of magnesium silicates could be considered as alternative for the extraction of pure magnesium compounds. The literature is relatively poor in this field. This paper describes preliminary results about this topic. It is a part of a larger program devoted to the study of chlorine technology.[1-3]

Ishii et al.[4] studied the chlorination of $\mathrm{FeO}, \mathrm{Fe}_{2} \mathrm{O}_{3}, \mathrm{SiO}_{2}, \mathrm{MgO}$ as well as olivine, protoenstatite and talc between $25^{\circ} \mathrm{C}$ and $1000{ }^{\circ} \mathrm{C}$ using differential thermal and thermogravimetric analysis (DTA and TGA). According to these authors, the reactivity of $\mathrm{MgO}$ towards chlorine is negligible at $640{ }^{\circ} \mathrm{C}$ in absence of carbon. In its presence, an exothermic peak is observed at $500{ }^{\circ} \mathrm{C}$ corresponding to the formation of $\mathrm{MgCl}_{2}$. This peak shifts to lower temperatures with increasing the amount of carbon. An endothermic peak was observed at about to $700{ }^{\circ} \mathrm{C}$ and attributed to the fusion of $\mathrm{MgCl}_{2}$. The initial reaction rate was rapid. However, as the reaction progresses, its rate decreases and finally stopped completely at about 55 pct of $\mathrm{MgO}$ chlorination. The authors suggest that $\mathrm{MgCl}_{2}$ formed on the surface of the $\mathrm{MgO}$ particles acts as a barrier for further progress of the reaction. They also indicated that chlorination of olivine is only possible in presence of carbon and suggested that two types of magnesium coexist in this solid having different reactivities towards chlorine. Protoenstatite and talc give exothermic peaks at $950{ }^{\circ} \mathrm{C}$ and $750{ }^{\circ} \mathrm{C}$, respectively. Equations 1 and 2 describe respectively the interaction of olivine and protoenstatite with $\mathrm{Cl}_{2}+\mathrm{C}$ corresponding to these exothermic peaks, while the chlorination of talc proceeded together with its decomposition following equation 3 .

$$
\begin{aligned}
\mathrm{Mg}_{2} \mathrm{SiO}_{4}+\mathrm{C}+\mathrm{Cl}_{2} & \rightarrow \mathrm{MgSiO}_{3}+\mathrm{MgCl}_{2}+\mathrm{CO} \\
\mathrm{MgSiO}_{3}+1 / 4 \mathrm{C}+1 / 4 \mathrm{Cl}_{2} & \rightarrow 3 / 4 \mathrm{MgSiO}_{3}+1 / 4 \mathrm{MgCl}_{2}+1 / 4 \mathrm{SiO}_{2}+1 / 4 \mathrm{CO} \\
\mathrm{Mg}_{3}\left(\mathrm{Si}_{2} \mathrm{O}_{5}\right)_{2}(\mathrm{OH})_{2} & \rightarrow 3 \mathrm{MgSiO}_{3}+\mathrm{SiO}_{2}+\mathrm{H}_{2} \mathrm{O}
\end{aligned}
$$

\section{THERMODYNAMIC STUDY}

Olivine and serpentine natural samples contain iron impurities. The evolution of the standard free energy changes $\left(\Delta \mathrm{G}^{\circ}\right)$ of chlorination of $\mathrm{MgO}, \mathrm{FeO}, \mathrm{Mg}_{2} \mathrm{SiO}_{4}, \mathrm{MgSiO}_{3}$ and $\mathrm{SiO}_{2}$ by chlorine (Eqs. 4 to 10 ) and by $\mathrm{Cl}_{2}+\mathrm{CO}$ (Eqs. 11 to 17) are calculated using data of references 5 and 6 . Figures 1 and 2 show the evolution of standard free energy changes, as a function of temperature, for the chlorination and carbochlorination of the considered reactions. Only the chlorination of FeO 
by chlorine is thermodynamically favorable in whole explored temperature range. On the other hand, $\Delta \mathrm{G}^{\circ}$ of $\mathrm{MgO}$ chlorination is slightly positive at temperatures higher than about $500{ }^{\circ} \mathrm{C}$, while the chlorination of $\mathrm{SiO}_{2}$ is thermodynamically unfavorable up to $1000{ }^{\circ} \mathrm{C}$. However, in the presence of a reducing atmosphere, all the carbochlorination reactions are thermodynamically favorable in the investigated temperature range.

\begin{tabular}{|c|c|c|c|c|c|c|c|c|c|c|c|c|c|}
\hline & $\mathrm{MgO}$ & $+\mathrm{Cl}_{2}$ & & & $\rightarrow$ & & & & & $\mathrm{MgCl}_{2}$ & $+1 / 2$ & $\mathrm{O}_{2}$ & [4] \\
\hline \multirow[t]{2}{*}{$2 / 3$} & $\mathrm{FeO}$ & $+\mathrm{Cl}_{2}$ & & & $\rightarrow$ & & & & $2 / 3$ & $\mathrm{FeCl}_{3}$ & $+1 / 3$ & $\mathrm{O}_{2}$ & 5] \\
\hline & $\mathrm{Mg}_{2} \mathrm{SiO}_{4}$ & $+\mathrm{Cl}_{2}$ & & & $\rightarrow$ & & $\mathrm{MgSiO}_{3}$ & + & & $\mathrm{MgCl}_{2}$ & $+1 / 2$ & $\mathrm{O}_{2}$ & \\
\hline \multirow[t]{2}{*}{$1 / 4$} & $\mathrm{Mg}_{2} \mathrm{SiO}_{4}$ & $+\mathrm{Cl}_{2}$ & & & $\rightarrow$ & $1 / 2$ & $\mathrm{MgCl}_{2}$ & + & $1 / 4$ & $\mathrm{SiCl}_{4}$ & $+1 / 2$ & $\mathrm{O}_{2}$ & \\
\hline & $\mathrm{MgSiO}_{3}$ & $+\mathrm{Cl}_{2}$ & & & $\rightarrow$ & & $\mathrm{MgCl}_{2}$ & + & & $\mathrm{SiO}_{2}$ & $+1 / 2$ & $\mathrm{O}_{2}$ & \\
\hline $1 / 3$ & $\mathrm{MgSiO}_{3}$ & $+\mathrm{Cl}_{2}$ & & & $\rightarrow$ & $1 / 3$ & $\mathrm{MgCl}_{2}$ & + & $1 / 3$ & $\mathrm{SiCl}_{4}$ & $+1 / 2$ & $\mathrm{O}_{2}$ & \\
\hline \multirow[t]{2}{*}{$1 / 2$} & $\mathrm{SiO}_{2}$ & $+\mathrm{Cl}_{2}$ & & & $\rightarrow$ & & & & $1 / 2$ & $\mathrm{SiCl}_{4}$ & $+1 / 2$ & $\mathrm{O}_{2}$ & [10] \\
\hline & $\mathrm{MgO}$ & $+\mathrm{Cl}_{2}$ & + & $\mathrm{CO}$ & $\rightarrow$ & & & & & $\mathrm{MgCl}_{2}$ & + & $\mathrm{CO}_{2}$ & 1 \\
\hline \multirow[t]{2}{*}{$2 / 3$} & $\mathrm{FeO}$ & $+\mathrm{Cl}_{2}$ & $+2 / 3$ & $\mathrm{CO}$ & $\rightarrow$ & & & & $2 / 3$ & $\mathrm{FeCl}_{3}$ & $+2 / 3$ & $\mathrm{CO}_{2}$ & 12] \\
\hline & $\mathrm{Mg}_{2} \mathrm{SiO}_{4}$ & $+\mathrm{Cl}_{2}$ & + & $\mathrm{CO}$ & $\rightarrow$ & & $\mathrm{MgSiO}_{3}$ & + & & $\mathrm{MgCl}_{2}$ & + & $\mathrm{CO}_{2}$ & 13 \\
\hline \multirow[t]{2}{*}{$1 / 4$} & $\mathrm{Mg}_{2} \mathrm{SiO}_{4}$ & $+\mathrm{Cl}_{2}$ & + & $\mathrm{CO}$ & $\rightarrow$ & $1 / 2$ & $\mathrm{MgCl}_{2}$ & + & $1 / 4$ & $\mathrm{SiCl}_{4}$ & + & $\mathrm{CO}_{2}$ & {$[14$} \\
\hline & $\mathrm{MgSiO}_{3}$ & $+\mathrm{Cl}_{2}$ & + & $\mathrm{CO}$ & $\rightarrow$ & & $\mathrm{MgCl}_{2}$ & + & & $\mathrm{SiO}_{2}$ & + & $\mathrm{CO}_{2}$ & {$[15]$} \\
\hline $1 / 3$ & $\mathrm{MgSiO}_{3}$ & $+\mathrm{Cl}_{2}$ & + & $\mathrm{CO}$ & $\rightarrow$ & $1 / 3$ & $\mathrm{MgCl}_{2}$ & + & $1 / 3$ & $\mathrm{SiCl}_{4}$ & + & $\mathrm{CO}_{2}$ & {$[16$} \\
\hline $1 / 2$ & $\mathrm{SiO}_{2}$ & $+\mathrm{Cl}_{2}$ & + & $\mathrm{CO}$ & $\rightarrow$ & & & & $1 / 2$ & $\mathrm{SiCl}_{4}$ & + & $\mathrm{CO}_{2}$ & \\
\hline
\end{tabular}

Figure 3 shows the phase stability diagrams for the $(\mathrm{Mg}, \mathrm{Fe}, \mathrm{Si})-\mathrm{O}-\mathrm{Cl}$ systems at $800{ }^{\circ} \mathrm{C}$. These diagrams are established using data of reference 6. The estimated experimental partial pressures of $\mathrm{Cl}_{2}$ and $\mathrm{O}_{2}$ are indicated in these diagrams for the different chlorination atmospheres. According to these diagrams, oxides of the three elements will react with chlorine in the presence of $\mathrm{CO}$ at $800{ }^{\circ} \mathrm{C}$, whereas with the $\mathrm{Cl}_{2}+\mathrm{N}_{2}$ gas mixture, only iron oxide and $\mathrm{MgO}$ could be chlorinated. The thermodynamic probability of chlorination of all the oxides decreases as the oxygen partial pressure increases.

\section{MATERIALS AND EXPERIMENTAL PROCEDURE}

Natural olivine and serpentine are used for this investigation. X-ray diffraction (XRD) and scanning electron microscope (SEM) analyses of samples are summarized in Figure 4. The main phases identified in these samples are $\mathrm{Mg}_{2} \mathrm{SiO}_{4}$ and $\mathrm{Mg}_{3} \mathrm{Si}_{2} \mathrm{O}_{5}(\mathrm{OH})_{4}$, respectively. However, SEM analysis indicated the presence of iron compounds in these solids. Thermogravimetric (TG) 
chlorination tests were realized with $100 \mathrm{mg}$ of sample, using the experimental procedure described previously[1]. The furnace's heating rate was about $25^{\circ} \mathrm{C} / \mathrm{min}$.

The oxy- and carbochlorination tests with these samples were carried out in a horizontal experimental set described in reference[1]. This set is essentially composed of a gas metering unit followed by a gas purification one and an automatically controlled electrical furnace. The outlet gas mixture is cooled to condense and to recover volatile chlorides. The exhausted gas mixture is purified before its release to the atmosphere. The reaction products were subjected to SEM and XRD analysis for the identification of formed phases.

\section{RESULTS AND DISCUSSION}

\section{A. Non-isothermal TG measurements}

1. Oxychlorination

Figure 5 traces the evolution of the percent (pct) weight loss of olivine and serpentine samples versus temperature during their treatments in $\mathrm{Cl}_{2}+$ air gas mixture. The reaction of olivine with this gas mixture starts by a slight weight increase probably due to chlorine adsorption on the sample's surface. The $\mathrm{Mg}_{2} \mathrm{SiO}_{4}$ sample's weight loss starts at temperature higher than $750{ }^{\circ} \mathrm{C}$. Its reaction rate is low and its weight loss is less than 5 pct even at temperatures approaching $1000{ }^{\circ} \mathrm{C}$. This weight loss is probably due to the chlorination of the iron impurities and the volatilization of the formed ferric chloride.

For temperatures less than $500{ }^{\circ} \mathrm{C}$, the serpentine' weight loss is about 1 pct. This weight change is attributed to adsorbed water and partially to constituted one. At temperatures higher than $500{ }^{\circ} \mathrm{C}$, the sample's weight loss is about 16 pct. Treatment of $\mathrm{Mg}_{3} \mathrm{Si}_{2} \mathrm{O}_{5}(\mathrm{OH})_{4}$ in nitrogen and using the same experimental conditions leads to a weight loss of about 13 pct that is equal to the calculated weight loss using equation 18 . This is probably due to the thermal decomposition of the serpentine and subsequent volatilization of $\mathrm{H}_{2} \mathrm{O}$ as described by the following equation.

$$
\mathrm{Mg}_{3} \mathrm{Si}_{2} \mathrm{O}_{5}(\mathrm{OH})_{4} \quad \rightarrow \quad \mathrm{Mg}_{2} \mathrm{SiO}_{4}+\mathrm{MgSiO}_{3}+2 \mathrm{H}_{2} \mathrm{O}
$$

Consequently, the weight loss of $\mathrm{Mg}_{3} \mathrm{Si}_{2} \mathrm{O}_{5}(\mathrm{OH})_{4}$, about 3 pct, may be attributed to the chlorination of the iron bearing compounds and the volatilization of $\mathrm{FeCl}_{3}$. XRD of the reaction products shows the presence of $\mathrm{Mg}_{2} \mathrm{SiO}_{4}$ and $\mathrm{MgSiO}_{3}$. One may underline that $\mathrm{MgSiO}_{3}$ is thermodynamically stable in $\mathrm{Cl}_{2}$ as indicated by reactions 8 and 9 (Fig. 1). 


\section{Chlorination}

TG chlorination curves of $\mathrm{Mg}_{2} \mathrm{SiO}_{4}$ and $\mathrm{Mg}_{3} \mathrm{Si}_{2} \mathrm{O}_{5}(\mathrm{OH})_{4}$ in the $\mathrm{Cl}_{2}+\mathrm{N}_{2}$ atmosphere are shown in Figure 6 . The curve of olivine indicates that the reactivity of olivine towards the chlorination gas mixture is low. This is in good agreement with the thermodynamic considerations (Figure 1). Only the iron bearing compounds were probably chlorinated up to $1000{ }^{\circ} \mathrm{C}$. The behavior of serpentine in $\mathrm{Cl}_{2}+\mathrm{N}_{2}$ is almost identical to that in $\mathrm{Cl}_{2}+$ air. However, the obtained weight loss is slightly higher than that corresponding to the thermal decomposition of this solid.

\section{Carbochlorination}

As expected from the thermodynamic calculations, the carbochlorination of these solids is more favorable than their chlorination with $\mathrm{Cl}_{2}+\mathrm{N}_{2}$ or $\mathrm{Cl}_{2}+$ air. Figure 7 traces the pct weight loss curves versus temperature for the chlorination of magnesium bearing compounds. The olivine begins to react with $\mathrm{Cl}_{2}+\mathrm{CO}$ at about $600{ }^{\circ} \mathrm{C}$. The sample weight increases with the temperature rise up to $900{ }^{\circ} \mathrm{C}$. The stabilization of weight loss, beyond this temperature, is due to the overlapping of the sample's rates of carbochlorination and that of $\mathrm{MgCl}_{2}$ volatilization. The curve of the serpentine carbochlorination first exhibits a weight loss from $500{ }^{\circ} \mathrm{C}$ to $700{ }^{\circ} \mathrm{C}$ attributed to its thermal decomposition. At temperatures higher than $700{ }^{\circ} \mathrm{C}$, the weight increase is due to the formation of $\mathrm{MgCl}_{2}$. Further weight loss above $900{ }^{\circ} \mathrm{C}$ is due to the volatilization of magnesium chloride. One may underline that boiling point of $\mathrm{MgCl}_{2}$ is $1412{ }^{\circ} \mathrm{C}[7]$.

\section{B. Isothermal Treatment in the Horizontal Experimental Set}

\section{Oxychlorination}

Following the preliminary experimentation on the chlorination behavior of these samples in non-isothermal conditions, a series of experiments was performed under isothermal conditions in the temperature range of $500{ }^{\circ} \mathrm{C}$ and $1000{ }^{\circ} \mathrm{C}$ for a reaction time of two hours using about 3 grams. Figure 8 groups the evolution of pct weight loss of samples as a function of temperature.

The reactivity of olivine towards $\mathrm{Cl}_{2}$ +air is low even for a reaction time of two hours. The observed weight loss of about 8 pct at $1000{ }^{\circ} \mathrm{C}$ corresponds probably to the chlorination of iron oxide contained in the sample and probably to partial chlorination of this sample. Analysis of residue shows the presence of $\mathrm{Mg}_{2} \mathrm{SiO}_{4}$ (Table I) as the only stable phase in all residues obtained by the oxychlorination of olivine. The reaction of serpentine with the oxychlorinating gas mixture 
started after its thermal decomposition according to Eq. 18. Again, the chlorination rate of serpentine is low even at $1000{ }^{\circ} \mathrm{C}$. As it is shown in Table I, the XRD analysis confirms the decomposition of serpentine at temperatures higher than $600{ }^{\circ} \mathrm{C}$ and the formation of $\mathrm{Mg}_{2} \mathrm{SiO}_{4}$ and $\mathrm{MgSiO}_{3}$. The absence of magnesium chloride in the reaction product, if formed, can be justified by its volatilization because of the important linear velocity of the gas mixture (about $50 \mathrm{~cm} / \mathrm{min}$.).

Table I - XRD Analysis of the Oxychlorination Residues.

\begin{tabular}{lllll}
\hline \multirow{2}{*}{ Solid } & \multicolumn{5}{c}{ Temperature of Treatment, ${ }^{\circ} \mathrm{C}$} \\
\cline { 2 - 5 } & 500 & 600 & 800 & 1000 \\
\hline Olivine & $\mathrm{Mg}_{2} \mathrm{SiO}_{4}$ & $\mathrm{Mg}_{2} \mathrm{SiO}_{4}$ & $\mathrm{Mg}_{2} \mathrm{SiO}_{4}$ & $\mathrm{Mg}_{2} \mathrm{SiO}_{4}$ \\
Serpentine & $\mathrm{Mg}_{3} \mathrm{Si}_{2} \mathrm{O}_{5}(\mathrm{OH})_{4}$ & $\mathrm{Mg}_{3} \mathrm{Si}_{2} \mathrm{O}_{5}(\mathrm{OH})_{4}$ & $\mathrm{Mg}_{2} \mathrm{SiO}_{4}, \mathrm{MgSiO}_{3}$ & $\mathrm{Mg}_{2} \mathrm{SiO}_{4}, \mathrm{MgSiO}_{3}$ \\
\hline
\end{tabular}

\section{Carbochlorination}

Figure 9 shows the evolution of pct weight loss of olivine and serpentine samples during their carbochlorination between $500{ }^{\circ} \mathrm{C}$ and $1000{ }^{\circ} \mathrm{C}$. The olivine sample reacts with the gas mixture at $500{ }^{\circ} \mathrm{C}$ leading to a weight increase. Between 600 and $700{ }^{\circ} \mathrm{C}$, the weight loss remained constant. This observation agrees with that of Ishii et al. ${ }^{[4]}$ concerning the presence two types of magnesium, present in the olivine, having different reactivities for the chlorination. Table II confirms the presence of $\mathrm{Mg}_{2} \mathrm{SiO}_{4}$ and $\mathrm{MgSiO}_{3}$. For temperatures higher than $800{ }^{\circ} \mathrm{C}$, the volatilization of $\mathrm{MgCl}_{2}$ begins leading to a decrease of the sample's weight. As indicated by XRD results of Table II, the phases detected in the chlorination residue are $\mathrm{Mg}_{2} \mathrm{SiO}_{4}$ and $\mathrm{MgCl}_{2}$ at $500{ }^{\circ} \mathrm{C}$ and $600{ }^{\circ} \mathrm{C}$. $\mathrm{MgSiO}_{3}$ was identified at temperatures equal or higher than $800{ }^{\circ} \mathrm{C}$ and confirms the reaction described by equation 13 . The carbochlorination of olivine is incomplete even at $1000{ }^{\circ} \mathrm{C}$. This is because of the formation of a magnesium chloride and amorphous silica layer that acts as a barrier between the rest of olivine and the carbochlorinating gas mixture. This hypothesis is confirmed by the presence of only $\mathrm{MgCl}_{2}$ as revealed by XRD and that of amorphous silica identified by the SEM analysis.

Serpentine reacted with the $\mathrm{Cl}_{2}+\mathrm{CO}$ gas mixture at $500{ }^{\circ} \mathrm{C}$. The observed weight loss up to $800{ }^{\circ} \mathrm{C}$ is the algebraic sum of the weight increase due to the chlorination of the iron and magnesium compounds and the weight loss due to the thermal decomposition of the sample (Eq. 18) and the volatilization of $\mathrm{FeCl}_{3}$ and $\mathrm{MgCl}_{2}$. At higher temperatures, the rate of volatilization of $\mathrm{MgCl}_{2}$ seems to be higher than that of its formation. This is confirmed by the presence of silicates in the residue treated at $1000{ }^{\circ} \mathrm{C}$ (Table II). 
Table II - XRD Analysis of the Carbochlorination Residues.

\begin{tabular}{lllll}
\hline Solid & \multicolumn{4}{c}{ Temperature of Treatment ${ }^{\circ} \mathrm{C}$} \\
\cline { 2 - 5 } & 500 & 600 & 800 & 1000 \\
\hline Olivine & $\mathrm{Mg}_{2} \mathrm{SiO}_{4}, \mathrm{MgCl}_{2}$ & $\mathrm{Mg}_{2} \mathrm{SiO}_{4}, \mathrm{MgCl}_{2}$ & $\mathrm{Mg}_{2} \mathrm{SiO}_{4}, \mathrm{MgSiO}_{3}, \mathrm{MgCl}_{2}$ & $\mathrm{MgCl}_{2}$ \\
Serpentine & $\mathrm{Mg}_{3} \mathrm{Si}_{2} \mathrm{O}_{5}(\mathrm{OH})_{4}$ & $\mathrm{MgCl}_{2}$ & $\mathrm{Mg}_{2} \mathrm{SiO}_{4}, \mathrm{MgSiO}_{3}, \mathrm{MgCl}_{2}$ & $\mathrm{Mg}_{2} \mathrm{SiO}_{4}, \mathrm{MgSiO}_{3}$ \\
\hline
\end{tabular}

* $\mathrm{MgCl}_{2}$ is identified as $\mathrm{MgCl}_{2} \cdot 6 \mathrm{H}_{2} \mathrm{O}$.

\section{CONCLUSIONS}

The reactivity of $\mathrm{Mg}_{2} \mathrm{SiO}_{4}$ and $\mathrm{Mg}_{3} \mathrm{Si}_{2} \mathrm{O}_{5}(\mathrm{OH})_{4}$ towards oxychlorinating and chlorinating gas mixtures is low. In both cases, only the iron contained in these minerals is chlorinated and volatilzed at temperatures lower than $1000{ }^{\circ} \mathrm{C}$. At temperatures higher than $500{ }^{\circ} \mathrm{C}$, the serpentine is thermally decomposed. These results shows that the elimination of the iron compounds from these solids is possible through their chlorination in the temperature range of $800{ }^{\circ} \mathrm{C}$ to $1000{ }^{\circ} \mathrm{C}$

Chlorination and carbochlorination of serpentine and olivine start at about $500{ }^{\circ} \mathrm{C}$ and is incomplete at $1000{ }^{\circ} \mathrm{C}$. The serpentine is decomposed to $\mathrm{Mg}_{2} \mathrm{SiO}_{4}$ and $\mathrm{MgSiO}_{3}$ at temperatures lower than $800{ }^{\circ} \mathrm{C}$. The iron bearing compounds were fully chlorinated and volatilzed at temperatures lower than $900{ }^{\circ} \mathrm{C}$. The magnesium and iron chlorides are recovered by cooling the outlet gases to about $500{ }^{\circ} \mathrm{C}$ and $25^{\circ} \mathrm{C}$, respectively. The recovered magnesium chloride is of high purity and identified by XRD as $\mathrm{MgCl}_{2} \cdot 6 \mathrm{H}_{2} \mathrm{O}$. Such product can be used as a raw material for the fabrication of pure magnesium employed for the production of alloys devoted to the aeronautic sector.

\section{Acknowledgments}

This work was performed in the frame of contract $N^{\circ}$ BRE2-CT92-0173 thanks to the financial support of the European Union (DG-XII). The authors thank Dr. H. L. Schmidt for discussion, suggestion and help.

They also would like to thank Drs. J. C. Mugica (INASMET, San Sebastian, Spain) and M. Coelho (INETI, Lisbon, Portugal) for technical discussions. Authors are indebted to E. Allain, A. Bonazébi, M. Djona, S. Ivanaj, N. Mirghaffari for discussions and help on different subjects and to Mrs. C. Tanchel for technical and administrative support. 


\section{REFERENCES}

1. I. Gaballah and M. Djona, Metallurgical and Materials Transactions B, 1995, vol 26B, pp 41 -50 .

2. Djona M., Allain E. and Gaballah I., Metallurgical and Materials Transactions B, 1995, vol 26B, pp $703-710$.

3. N. Kanari and I. Gaballah, Proceeding of the Symposia sponsored by the Extraction and Processing Divison, TMS Annual Meeting, Edited by B. Mishra and Published by TMS, 1997, pp 57 - 71.

4. T. Ishii, R. Furuichi and Y. Kobayashi: Thermochim. Acta, 9, 1974, pp. 39-53.

5. A. Roine: in Outokumpu HSC Chemistry for Windows, Version 2.0, Outokumpu Research, Pori, Finland, May 1994.

6. I. Barin, Thermochemical data of pure substances, 1989, VCH.

7. Anonymous: Handbook of Chemistry and Physics, 74th edition, Editor-in-Chief D.R. Lide, CRC Press, Florida, USA, 1993-94, pp. 4-71 and 6-69.

\section{FIGURE CAPTIONS}

Figure 1 : Standard free energy change of chlorination reactions as a function of temperature $[5,6]$.

Figure 2 : Standard free energy change of carbochlorination reactions as a function of temperature $[5,6]$.

Figure 3 : Phase stability diagram of (a) $\mathrm{Mg}-\mathrm{O}-\mathrm{Cl}$, (b) $\mathrm{Fe}-\mathrm{O}-\mathrm{Cl}$ and (c) $\mathrm{Si}-\mathrm{O}-\mathrm{Cl}$ systems at $800{ }^{\circ} \mathrm{C}^{[5]}$.

Figure 4 : Results of SEM and XRD analyses of employed samples.

Figure 5 : Thermogravimetic analysis of magnesium compounds in $\mathrm{Cl}_{2}+$ air.

Figure 6 : Thermogravimetic analysis of magnesium compounds in $\mathrm{Cl}_{2}+\mathrm{N}_{2}$.

Figure 7 : Thermogravimetic analysis of magnesium compounds in $\mathrm{Cl}_{2}+\mathrm{CO}$.

Figure 8 : Oxychlorination of magnesium silicates in a horizontal set during 2 hours.

Figure 9 : Carbochlorination of olivine and serpentine in a horizontal set during 2 hours.

\section{TABLE CAPTIONS}

Table I : XRD Analysis of the Oxychlorination Residues.

Table II : XRD Analysis of the Carbochlorination Residues. 
Some Aspects of the Reactivity of Olivine and Serpentine towards Different Chlorinating Gas Mixtures

\section{Figures}




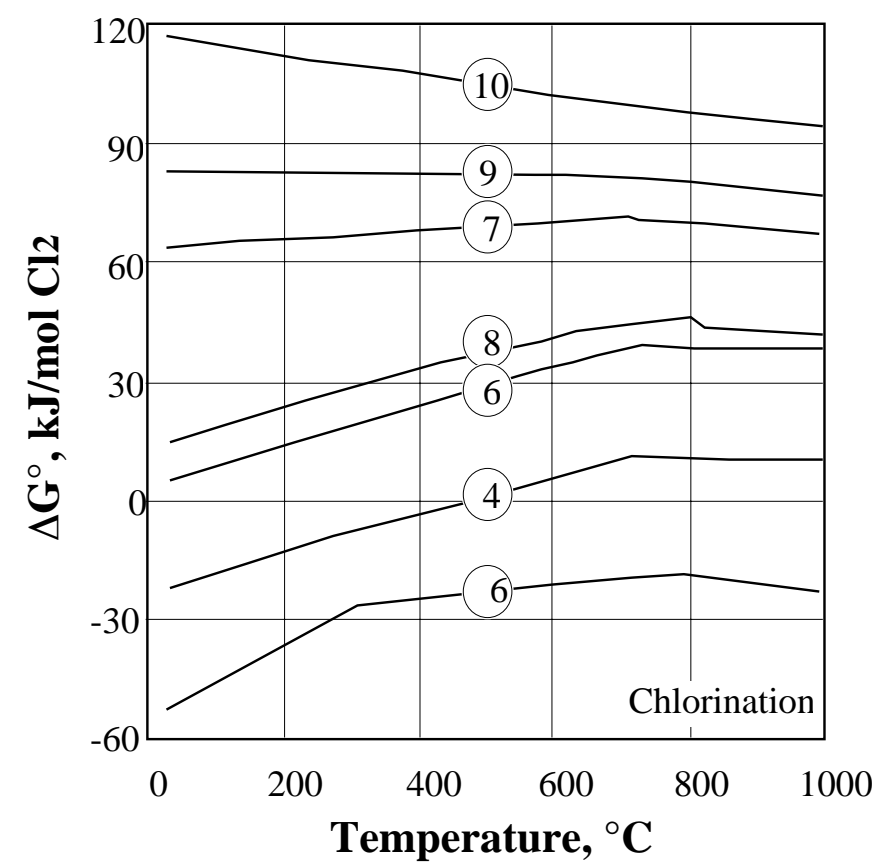

Figure 1 - Standard free energy change of chlorination reactions as a function of temperature ${ }^{[5,6]}$.

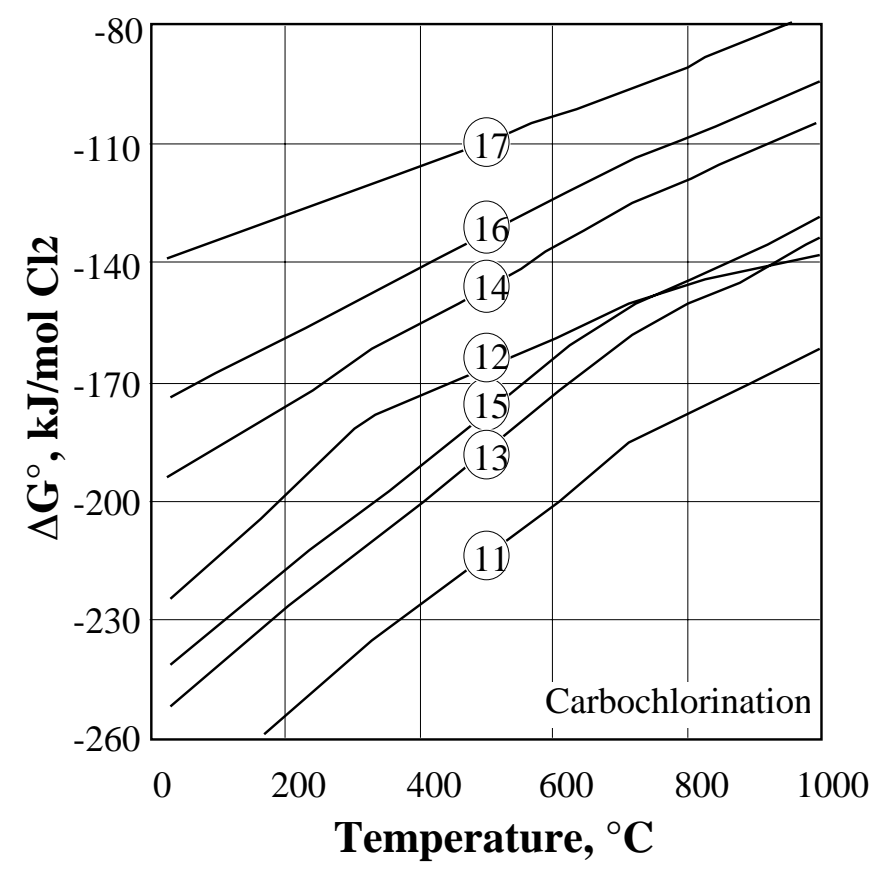

Figure 2 - Standard free energy change of carbochlorination reactions as a function of temperature $[5,6]$. 


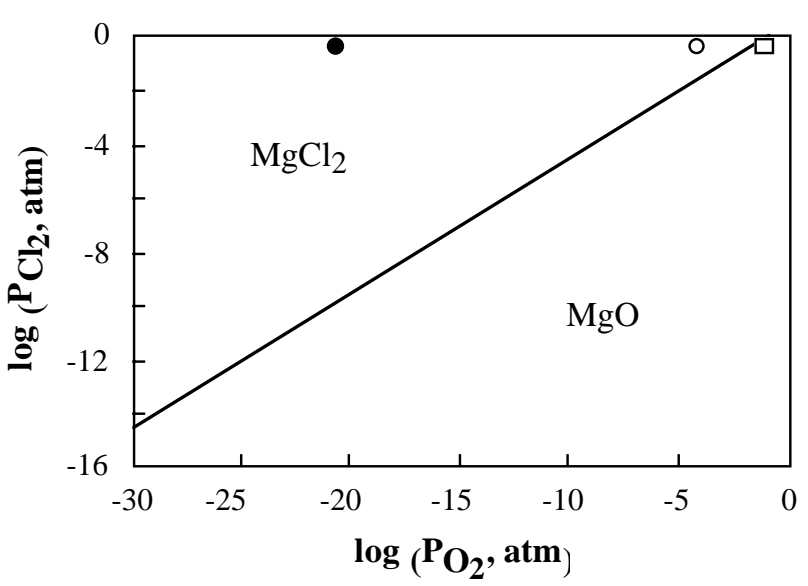

(a)

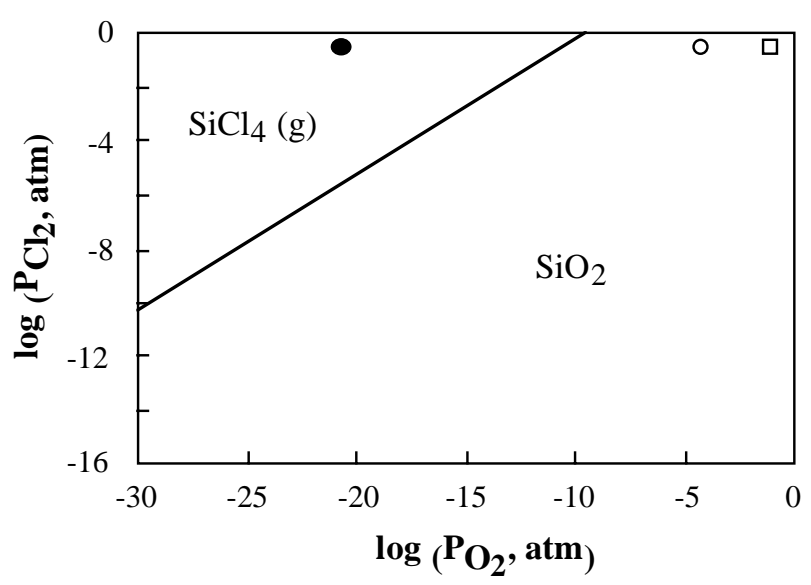

(c)

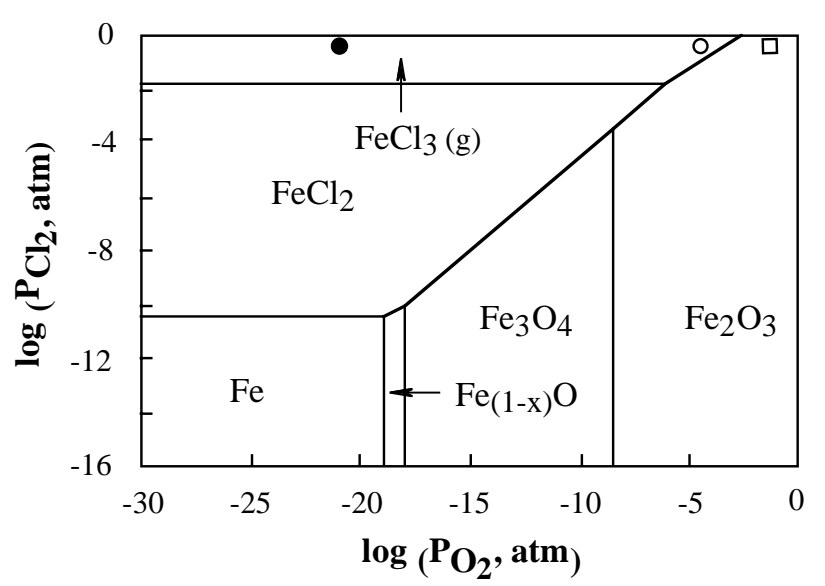

(b)

$\square$ : Estimated range of experimental conditions for oxychlorination,

$\mathrm{O}$ : Estimated range of experimental conditions for chlorination,

- : Estimated range of experimental conditions for carbochlorination.

Figure 3 - Phase stability diagram of (a) Mg-O$\mathrm{Cl}$, (b) $\mathrm{Fe}-\mathrm{O}-\mathrm{Cl}$ and (c) $\mathrm{Si}-\mathrm{O}-\mathrm{Cl}$ systems at $800{ }^{\circ} \mathrm{C}[5]$.

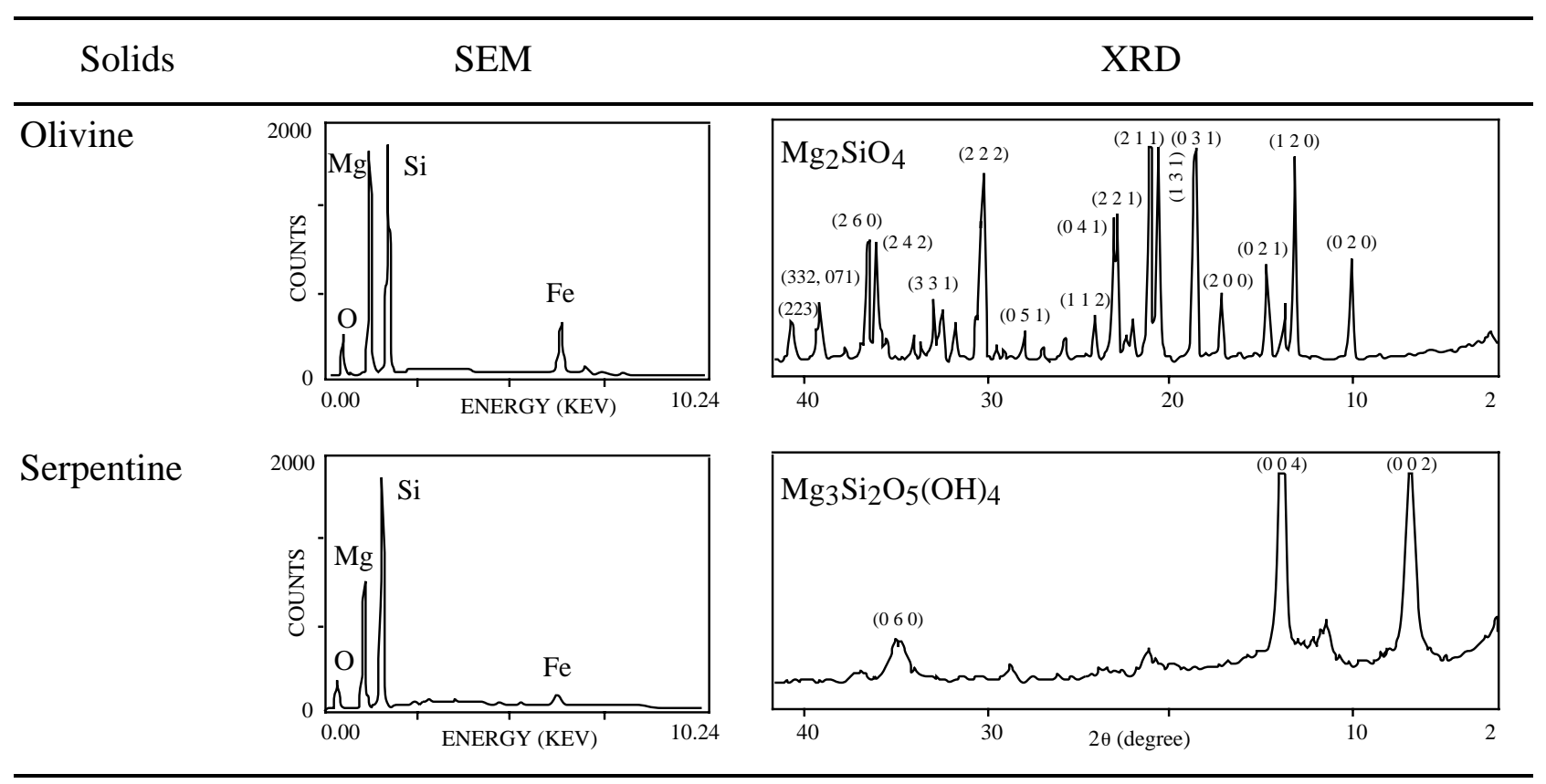

Figure 4 - Results of SEM and XRD analyses of employed samples. 


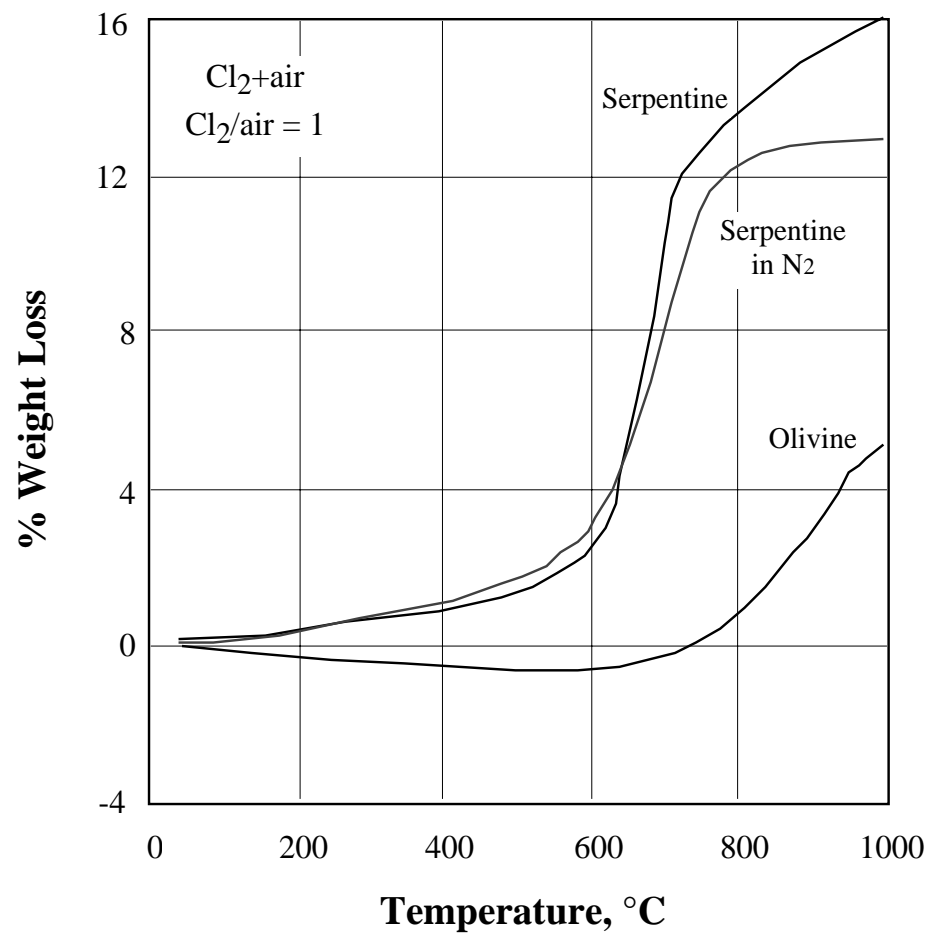

Figure 5 - Thermogravimetic analysis of magnesium compounds in $\mathrm{Cl}_{2}+$ air.

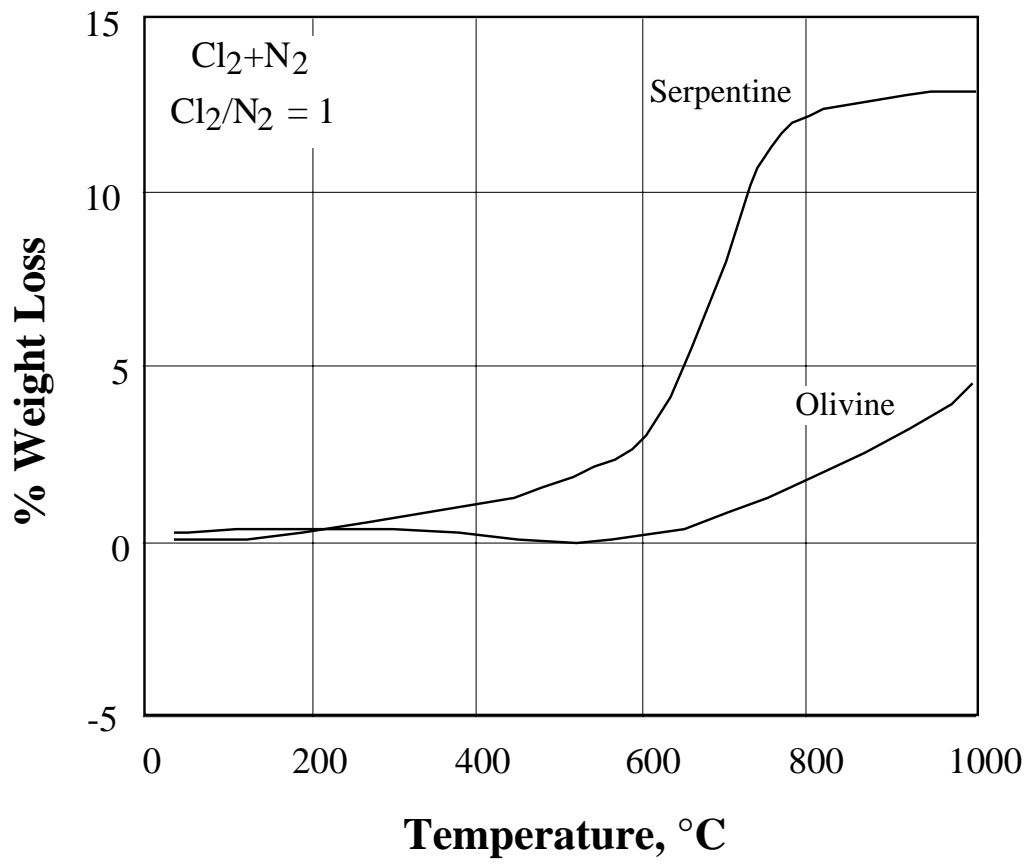

Figure 6 - Thermogravimetic analysis of magnesium compounds in $\mathrm{Cl}_{2}+\mathrm{N}_{2}$. 


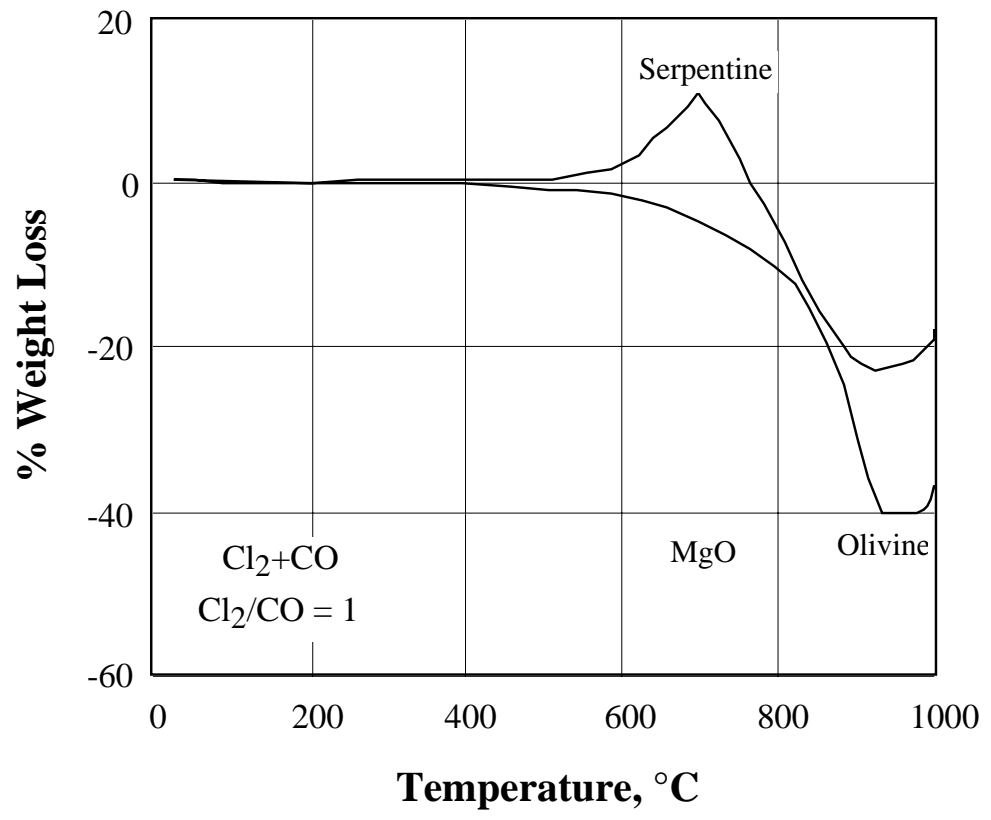

Figure 7 - Thermogravimetic analysis of magnesium compounds in $\mathrm{Cl}_{2}+\mathrm{CO}$.

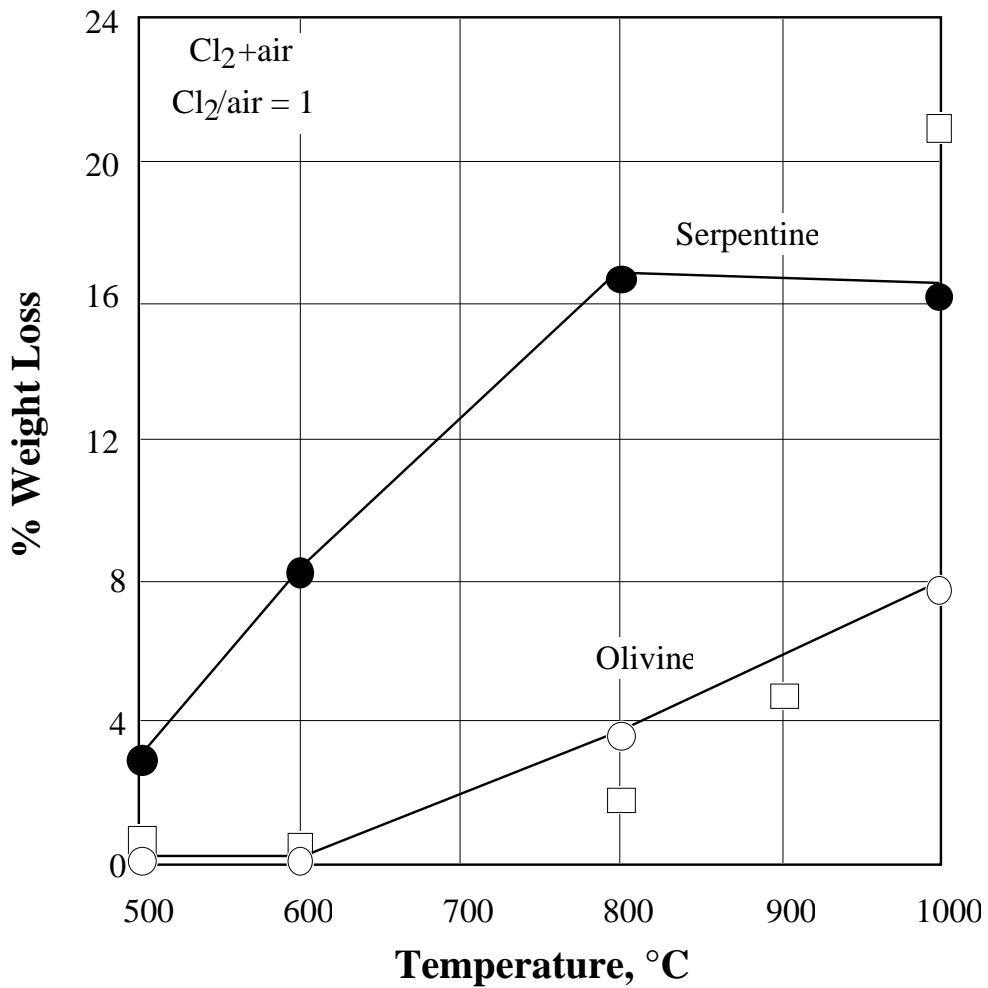

Figure 8 - Oxychlorination of magnesium silicates in a horizontal set during 2 hours. 


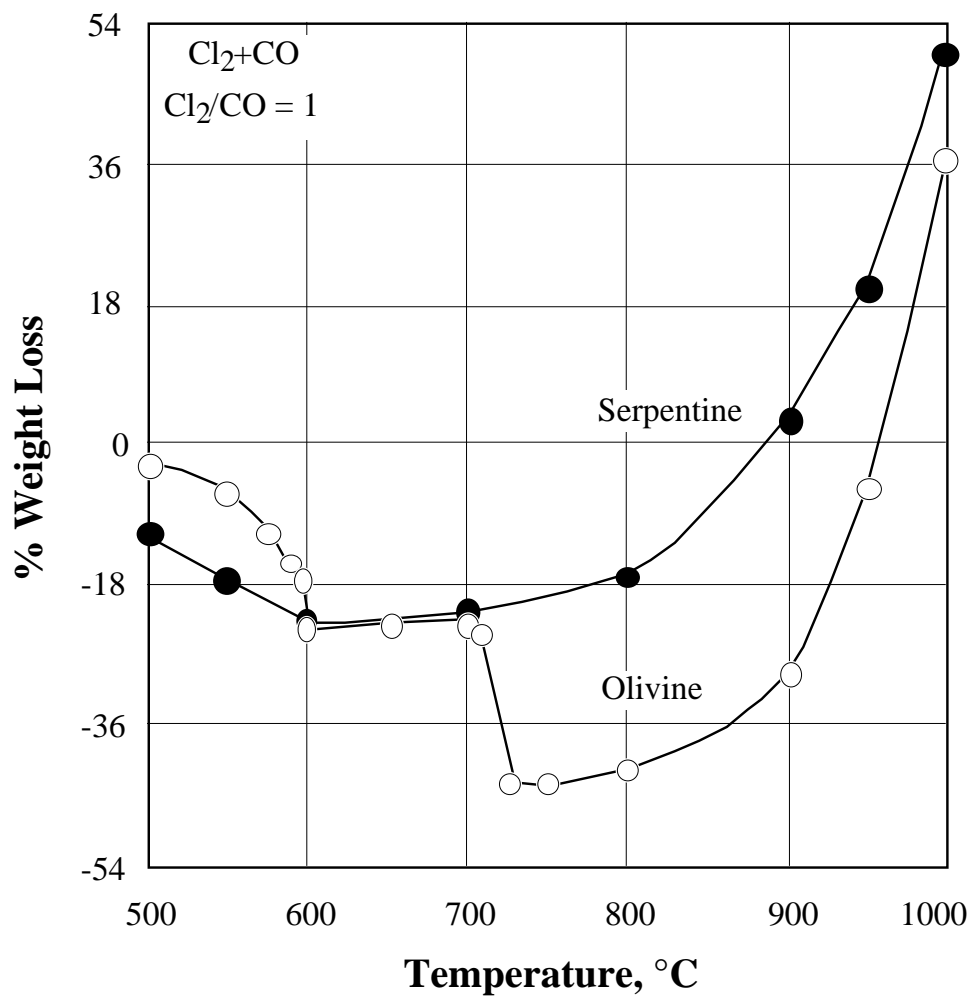

Figure 9 - Carbochlorination of olivine and serpentine in a horizontal set during 2 hours. 